\title{
The geology and hydrogeology of the Cassino plain (central Apennines, Italy): redefining the regional groundwater balance
}

\author{
Michele Saroli ${ }^{1} \cdot$ Michele Lancia $^{2,3} \cdot$ Marco Petitta $^{4}$
}

Received: 12 September 2018 / Accepted: 18 February 2019 / Published online: 9 March 2019

(C) The Author(s) 2019

\begin{abstract}
Cassino plain is a Quaternary intermontane basin of the central-southern Apennines, Italy. The plain has outstanding groundwater resources (total discharge of 23,000 L/s), thanks to the huge karst basins that surround the area. The area has been involved in many hydrogeological interests since the 1970s due to the economic importance and construction of the Western Campania Aqueduct for the water supply of Naples city and its hinterland. Despite its importance, the area lacks a common accepted hydrogeological conceptual model due to the complex geological setting. Two contrasting conceptual models already exist in the literature, with the first model based on a quantitative hydrogeological approach and the second on fieldwork. Through a literature analysis and further detailed field surveys, a new conceptual model is presented, acknowledging the thrust tectonics of the Apennine chain. The model unveils the most important hydrogeological issues of the area, serving as a useful tool for groundwater management, as well as for considering the changing anthropic and climate scenarios. In particular, the study redefines the hydrostructure extents and the groundwater flowpaths, characterizing the main water resources as Gari and Peccia springs.
\end{abstract}

Keywords Conceptual model $\cdot$ Groundwater management $\cdot$ Italy $\cdot$ Karst $\cdot$ Tectonics

\section{Introduction}

The karst basins of central Italy host huge groundwater resources, representing a strategic water resource (Ford and Williams 2007; Fiorillo et al. 2014). As a result, central Italy has numerous springs (Celico 1983; Boni et al. 1986) that guarantee a steady water supply to the main or smaller urban

Michele Lancia

lancia@sustc.edu.cn

1 Dipartimento di Ingegneria Civile e Meccanica, Universita` degli Studi di Cassino e del Lazio Meridionale, via G. Di Biasio 43, 03043 , Cassino, Italy

2 Guangdong Provincial Key Laboratory of Soil and Groundwater Pollution Control, School of Environmental Science and Engineering, Southern University of Science and Technology, Shenzhen 518055, China

3 State Environmental Protection Key Laboratory of Integrated Surface Water-Groundwater Pollution Control, School of Environmental Science and Engineering, Southern University of Science and Technology, Shenzhen 518055, China

4 Department of Earth Sciences, Sapienza University of Rome, P.le A. Moro 5, 00185, Rome, Italy areas. Because of its geological and hydrogeological setting, the Cassino plain represents one of the most important confluence points of groundwater flow, with discharges that vary from 18,000 to 23,000 L/s (Boni et al. 1986; Capelli et al. 2012). These groundwater resources have been extensively used since ancient times and, over time, there have been different schematizations and models of the geological and hydrogeological setting of the area. The first reported studies dealt with the structural and stratigraphic setting in the lowstand sectors (Franchi 1924; Novarese 1926; Beneo 1942) for the study of shallow and deep fluids. Zalaffi (1964) gives the first detailed geological work of the Cassino plain, describing a series of small Mesozoic carbonate structures, bounded by Quaternary continental deposits. The Quaternary continental series, studied in depth by Devoto (1965), is described as a lacustrine event that involved the Cassino plain and the Latina Valley (Fig. 1) from the middle to upper Pleistocene. Summarizing the previous study on the Apennine orogeny, Accordi (1966) proposed a thrust-andfold model for the Cassino plain; however, only a year later Accordi et al. (1967) assumed a horst-and-graben geometry, generating an unclear geological background. In the 1970 s, the exploitation of the groundwater resources heightened the scientific problem. Assuming the Zalaffi 


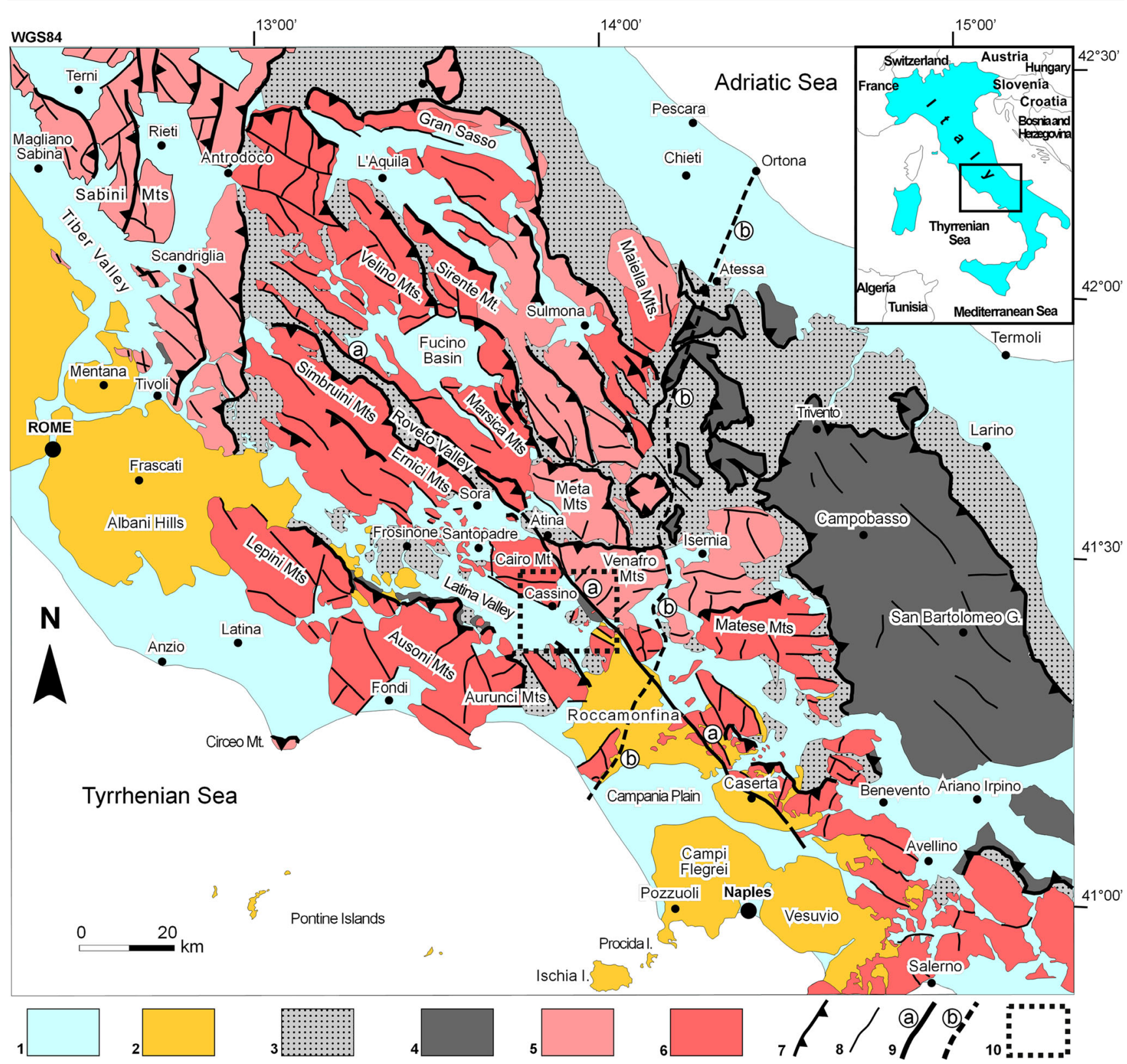

Fig. 1 Geological/hydrogeological structural map of central-southern Italy. Key to the legend: (1) Plio-Quaternary marine to continental clastic deposit; (2) Quaternary volcanic deposit; (3) Messinian to Tortonian foredeep clayey sequence; (4) Miocene to Oligocene clayey units of the Molise-Sannio basin (Sicilidi Auct.); (5) Miocene to Lias scarp and pelagic carbonate sequence; (6) Miocene to Trias shallow water carbonate sequence; (7) main thrust fronts; (8) normal contractional and/or strikeslip faults; (9) Val Roveto-Atina-Caserta, (a) tectonic alignment (Parotto and Praturlon 1976) and Ortona-Roccamonfina, (b) tectonic alignment (Locardi 1988); (10) limit of the studied area
(1964) model as valid, Boni and Bono (1974) supposed a groundwater flow of $4000 \mathrm{~L} / \mathrm{s}$ across the carbonate structure to justify a lack of hydrogeological balance for the Simbruini-Ernici-Cairo Mts. hydrostructure. In contrast, Celico and Stanganelli (1976) and Celico (1978, 1979, 1983) assumed a fold and structure model, based on a widespread campaign of mechanical and geophysical prospections combined with hydrogeological evidence; thus, a groundwater flux across the plain was rejected.
Some years later, based on new hydrogeological evidence and groundwater balances, Boni et al. (1986) considered the horst-and-graben geometry and the assumptions of Boni and Bono (1974) valid. Still, this hydrogeological debate remains unresolved, lacking a verified geological and hydrogeological conceptual model. Accordi and Carbone (1988) assumed a Mesozoic normal fault to justify the passage between the shallow water and the platform-to-basin domains across the Cassino plain (Val Roveto-Atina-Caserta line Auct.), while 
Cavinato and Sirna (1988) proposed a tectonic evolution strongly influenced by strike-slip tectonics. Corda and Brandano (2003) added new data about the distribution of the Miocene carbonate deposits of the Cassino plain, considering a unique depositional system from a regional point of view, whereas Saroli et al. (2014) analyzed the Cassino intermontane basin, evaluating the Quaternary evolution of a restricted sector. Recently, Lancia et al. (2018) have performed a numerical model across the Cassino plain to verify the continuity model of Boni et al. (1986) from a hydraulic point of view.

In order to individuate the best hydrogeological conceptual model to define the groundwater distribution and its preferential flow path, this study started with an in-depth review of the literature data. In literature, the discharge value of Gari and Peccia springs is cause for disagreement with respect to the validation of the conceptual model; thus, during this study, a pure quantitative approach was not followed and discharge measures were not repeated. Because the geological and the hydrogeological problems are strictly correlated, new geological surveys have been directed to the analysis of boreholes and unpublished data from water wells. A series of sampling programs and stratigraphic analyses, as well as hydrogeochemical and environmental isotope analyses, have been performed, in order to obtain a complete geological and hydrogeological framework of the problem. Following a multidisciplinary approach, this paper intends to: (1) review the literature of the Cassino area; (2) investigate the origin of the small carbonate structures and their structural and hydrogeological relationships with the surrounding structures; (3) define a fine-tuned groundwater model useful for the water management of these important water supply springs of central Italy.

\section{Materials and methods}

\section{Geological setting}

The Cassino plain is a Quaternary intermontane basin located in the lower Latina Valley of the central-southern Apennines (Fig. 1). The area shows a perturbed geological series created by the intersection of two major structural lines of the Apennine chain: the Ortona-Roccamonfina (Locardi 1988) and the Val Roveto-Atina-Caserta (Parotto and Praturlon 1976). The area is also affected by the superimposition of different tectonic phases related to the uplift and collapse of the Apennine chain (Centamore et al. 2007; Patacca and Sandone 2007; Cosentino et al. 2010). The area belongs to the Lazio-Abruzzi carbonate platform domain. The Mesozoic and Cenozoic stratigraphy consists of a pile of carbonate rocks, about 2,000 m thick (Accordi and Carbone 1988; Corda and Brandano 2003), overlain by terrigenous syn- orogenetic and post-orogenetic deposits (Accordi et al. 1967). The Val-Roveto-Atina Caserta line divides two different Mesozoic and Cenozoic stratigraphic sequences. The southwestern sector is constituted by a thick sequence of Mesozoic shallow-water carbonates followed by Miocene calcarenite ramp deposits. The Cairo Mt., the Rocca d'Evandro Mts. and the small reliefs of the Cassino plain (Fig. 2) belong to this sector. North of Cervaro-San Vittore (Fig. 2) platform-to-basin deposits outcrop with a reduced thickness of 1,000-1,500 m, due to stratigraphic hiatuses (Accordi and Carbone 1988). Tortonian sandstone (Flysch Auct.) and a gray clays unit (Unità Sicilidi Auct.) widely outcrop along the Latina Valley piedmont sectors. Upper Messinian to lower Pliocene clastic deposits (sands and gravels) lie in angular unconformity (Centamore et al. 2007; Pasquali et al. 2007) as described by geological surveys and mechanical prospections (Saroli et al. 2014). Middle Pleistocene lacustrine deposits and travertines filled the lowstand sectors of the Latina Valley (Devoto 1965), due to the interference with the Roccamonfina volcanism (Saroli et al. 2014). Reworked tuffs prove the passage from the lacustrine to the fluvial environment. Eventually, at $39.28 \pm 0.11 \mathrm{ka}$, Ignimbrite Campana (De Vivo et al. 2001) covered the whole continental sequence.

The presence of the Quaternary deposits and MesozoicCenozoic bedrock is strongly influenced by the structural evolution of the area. The structural setting is complex because of the superimposition of different tectonic phases (Centamore et al. 2007). The Lepini-Ausoni-W. Aurunci Mts. thrust (Fig. 1) propagated during the Upper Tortonian with a NW-SE trend and truncated in the SE by a lateral ramp (Cipollari and Cosentino 1995; Centamore et al. 2007). In the Lower Messinian, the uplift of the Apennine chain caused a main thrust located in the Roveto and Comino Valley (Fig. 1). The thrust has a NE-SW trend up to Atina and then folds with an $\mathrm{E}-\mathrm{W}$ direction. At Atina, the contact between the Cairo Mt. shallow-water carbonate sequences and the Venafro Mts. platform-to-basin sequences is visible (Fig. 1). This passage is strongly controlled by the tectonic processes, as supported by the interposition of Tortonian sandstones. Cavinato and Sirna (1988) consider the structural setting deeply influenced by left transpressive tectonics along the Val Roveto-Atina-Caserta-Valley line, triggered by a possible lateral ramp. Scrocca and Tozzi (2000) exclude a remarkable shortening between Cairo Mt. and Venafro Mts., comparing the analysis of the carbonate platform facies. Saroli et al. (2014) detect an anticline recumbent fold at regional scale in the Cassino area, supposing the presence of a lateral ramp between Cairo Mt. and the Venafro Mts. Conversely, the Eastern Aurunci sector has a simpler structural setting with several NE-SW monoclines. Centamore et al. (2007), based on the seismic sections of Cippitelli (2005), consider the Eastern Aurunci Mts. to be arranged 

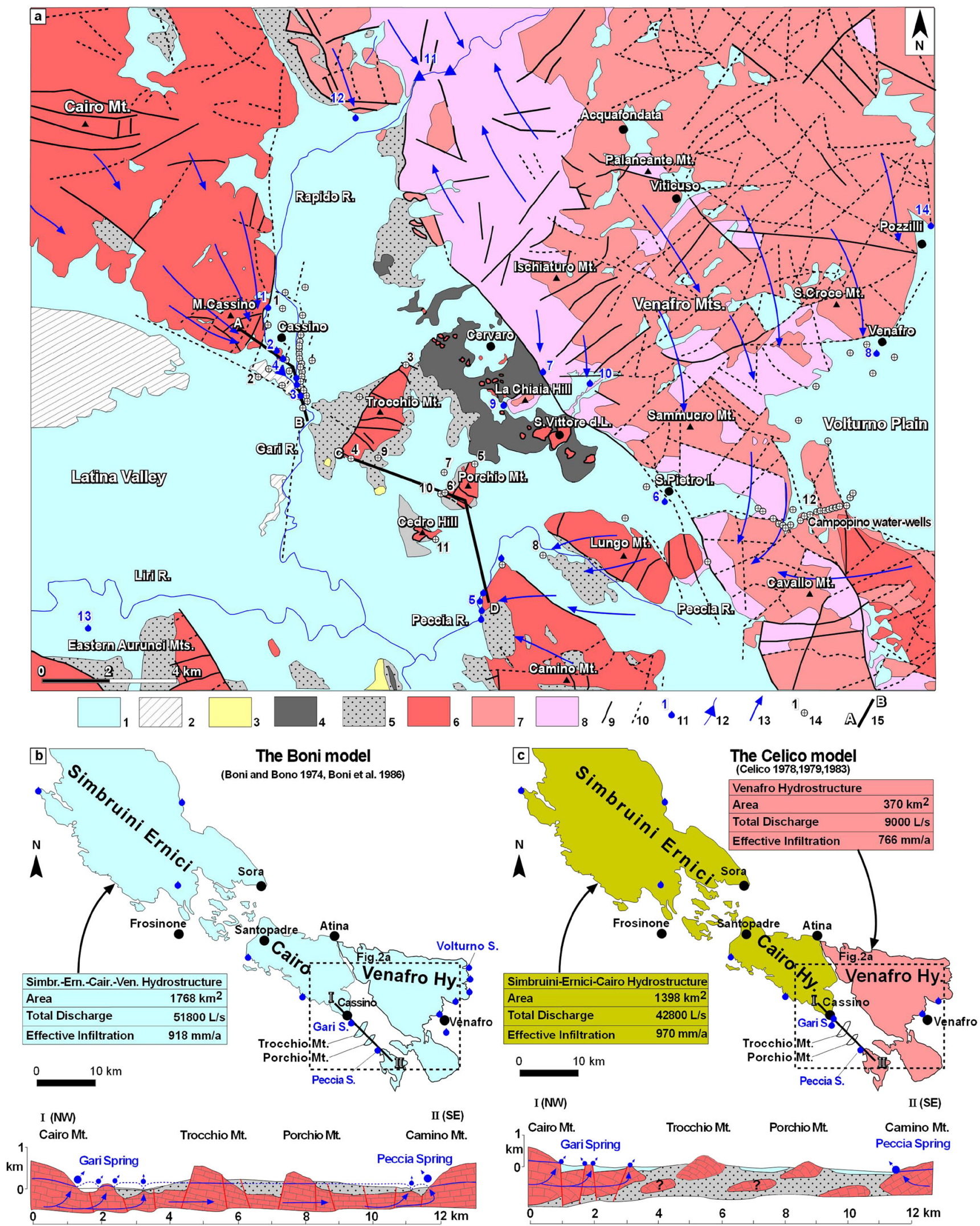
Fig. 2 Hydrogeological setting of the studied area. a Hydrogeological map of the Cassino plain. Key to the legend: (1) complex of the Quaternary deposits; (2) complex of the travertine; (3) complex of sand and gravel; (4) complex of the gray clays; (5) complex of the Tortonian sandstone; (6) complex of the slope deposits; (7) complex of the limestone; (8) Complex of the dolostone; (9) fault; (10) inferred fault; (11) spring, number indicates the spring name; (12) streambeds, number indicates the spring name; (13) groundwater flow direction; (14) boreholes number indicates main boreholes discussed in detail (Fig. 3); (15) trace section of Fig. 7a. b Regional setting of the karst hydrostructure with springs surrounding the Cassino plain, synthetic budget and hydrogeological section in accordance with the Boni model (redrawn from Boni and Bono 1974, Boni et al. 1986); c regional setting of the karst hydrostructures with springs surrounding the Cassino plain, synthetic budgets and hydrogeological section of the Celico model (redrawn from Celico 1978)

with an embricate thrust geometry with several minor thrust planes (Fig. 1).

During the Quaternary, the normal faulting event (Malinverno and Ryan 1986; Doglioni et al. 2004; Peccerillo 2005) deepened the Cassino basin, creating a horst and graben structure. The Cassino basin opened along four major faults (Saroli et al. 2014) with several Mesozoic horsts displaced in the Cassino urban and surrounding areas. Across the whole plain, the two major monoclines, Trocchio and Porchio Mts., have a NNW-SSE trend and are uplifted along three sides by normal faults. Stratigraphic and structural features are coincident with the Cairo Mt. and with the Rocca d'Evandro Mts. (Zalaffi 1964; Accordi et al. 1967; Corda and Brandano 2003).

\section{Hydrogeological setting}

The Cassino plain hosts two huge springs (Table 1; Fig. 2a), located on its northwestern and southeastern bounds, respectively the Gari spring (elevation of $41-30 \mathrm{~m}$ a.s.l. and discharge of 13,000-18,000 L/s) and Peccia spring (elevation of 29-25 m a.s.l. and discharge of 5,000 L/s). The springs are fed by the highly fractured and karstified Mesozoic-Cenozoic carbonate aquifers, which are surrounded by thick sequences of less permeable deposits (Fiorillo et al. 2014). Each carbonate basin, hydrogeologically isolated, represents an independent hydrostructure (sensu Boni et al. 1986). Stratigraphy and tectonics play a key role in both the characterization of groundwater flow and the identification of hydrostructure limits. In the study area, eight hydrogeological complexes have been distinguished, whereby the dolostone complex (Fig. 2a) represents the basal portion of the carbonate sequence, characterized by low porosity of the rock and an extended fracture network, often filled by carbonate silt, and the limestone complex (Fig. 2a) exhibits brittle behavior under tectonic stresses, favoring propagation and development of wide fracture networks that are locally karstified. Recharge is favored by the numerous sinkholes, dolines and karst depressions distributed along the topographic surface. In the fractured limestone complex, groundwater flow is concentrated towards the spring, and, lacking an impulsive response to the seasonal recharge, discharge is outstandingly high and steady (Petitta 2009; Tallini et al. 2013). The carbonate slope complex (Fig. 2a) shares the same hydrogeological properties as the limestone complex, yet the presence of ribbon chert and siliceous layers slightly reduces the permeability. The Tortonian sandstone complex (Fig. 2a) mainly consists of turbidite sequences with frequent layers of clays acting as a local aquitard, impeding the groundwater circulation. The gray clays complex (Fig. 2a), having very low permeability, represents the regional aquitard (sensu Boni et al. 1986). The low-stand sectors host young aquifers, with high porosity and high permeability, including the complex of the sands and conglomerates, the complex of the
Table 1 Spring elevation and discharge of the investigated area (Celico 1983, Boni et al. 1986, Capelli 2012). Numbers before spring names correspond to spring locations in Fig. 2a

\begin{tabular}{llr}
\hline Spring name & Elevation (m a.s.l.) & Discharge (L/s) \\
\hline 1. Cassino Urban Spring (Gari) & 39 & 125 \\
2. Terme Varroniane Spring (Gari) & $33-32$ & 5,800 \\
3. Borgo Mastronardi Spring (Gari) & $31-30$ & 1,900 \\
4. Gari Streambeds (Gari) & $38-30$ & 8,100 \\
5. Peccia Springs & $29-25$ & 5,000 \\
6. S. Maria dell'Acqua Springs & 140 & 10 \\
7. Acquacandida Spring & 272 & 11 \\
8. S. Bartolomeo Spring & 174 & 900 \\
9. Oliveto Scuro Spring & 224 & 27 \\
10. Sorgentina Springs & 245 & 18 \\
11. Rapido Streambeds & $375-230$ & 1,000 \\
12. Salauca Spring & $85-81$ & 250 \\
13. S. Giorgio Spring & 38 & 675 \\
14. S. Maria dell'Oliveto Spring & 210 & 500
\end{tabular}


Quaternary deposits, and the complex of the fractured travertines (Fig. 2a).

Hydrogeological works investigated the aforementioned carbonate sequence, defining a quantitative balance among the recharge area, the infiltration rate and the sum of the spring discharge. The infiltration rate for the limestone complex has been calculated to be approximately $1,000 \mathrm{~mm} / \mathrm{a}$ (Boni et al. 1986), a widely accepted estimation for the carbonate sequences of the central Apennines. Nevertheless, Boni and Bono (1974) outline an infiltration of $828 \mathrm{~mm} / \mathrm{a}$ for the Simbruini-Ernici-Cairo Mts. hydrostructure, with an expected discharge deficiency of 4,000 L/s; therefore, in a first schematization, Boni and Bono (1974) include the Peccia Springs in the Simbruini-Ernici-Cairo Mts. balance, supposing a groundwater flow throughout the Cassino subsoil along the Trocchio and Porchio Mts. (Fig. 2b). According to their reconstruction, Peccia spring can be included in the balance because the horst and graben geometry of the Cassino plain guarantees the carbonate continuity (Fig. 2b). Successively, Boni et al. (1986) include the Venafro Mts. within the Simbruini-Ernici-Cairo Mts. hydrostructure and presume the presence of streambeds with a discharge of 4,000 L/s in the upper stream portion of the Volturno River. The final balance of the Simbruini-ErniciCairo-Venafro Mts. suggests an average infiltration rate of $918 \mathrm{~mm} / \mathrm{a}$ (Fig. 2b). This estimated value is slightly lower than $1,000 \mathrm{~mm} / \mathrm{a}$ which can be attributed to the minor infiltration rate of the dolostone complex.

Conversely, Celico and Stanganelli (1976) study the groundwater model of the Venafro Mts. via new geophysical measures and mechanical prospections across the Cassino plain. They consider the Venafro Mts. an independent hydrostructure, feeding the Peccia springs. In their model, an infiltration of $766 \mathrm{~mm} / \mathrm{a}$ (Fig. 2c) is consistent because of the diffuse outcrop of dolostone and carbonate slope complex, which is characterized by a minor hydraulic conductivity. Adding more, Celico $(1978,1979,1983)$ points out the presence of a contractional superimposition of the Trocchio and the Porchio Mts. carbonate structure over the younger Tortonian sandstone (Fig. 2c). The Celico model does not completely clarify the hydrogeological balance of the Simbruini-Ernici-Cairo Mts. According to Celico's reconstruction, additional streambeds could be located in the lower sector of the Gari River (Fig. 2c), which would increase the infiltration rate from 828 to $970 \mathrm{~mm} / \mathrm{a}$ (Fig. 2c); however, recent quantitative studies from Capelli et al. (2012) deny the latter hypothesis, supporting the spring discharge data of Boni et al. (1986).

The described conceptual models are in conflict from a geological and hydrogeological point of view. In particular, the Boni model (Fig. 2c) is more conservative and considers only the latest normal faulting event. Conversely, the Celico model (Fig. 2c) assumes the thrust tectonic as predominant, following the previous work of Accordi (1966). The described problem is more than just an outdated geological debate because it will strongly influence management of the groundwater. In fact, the area provides the water resources for the Western Campania Aqueduct, a strategic water resource of Naples and its hinterland. A full characterization of the springs and a fine-tuned conceptual model is a necessary tool to manage this water resource, in light of the global climate changes which directly interfere with groundwater availability. Even if Gari and Peccia springs have a steady discharge, as pointed out in four decades of observations, climate changes could affect the minor springs at higher elevations. Exploited by the aqueduct companies for their minor costs of management (the higher elevation allows a cheaper water distribution), the discharge of these minor springs could decrease during prolonged droughts.

\section{The borehole data}

Because an accurate geological reconstruction is essential to creating an updated hydrogeological conceptual model, all available preexisting boreholes in the area have been analyzed. Stratigraphic information comes from the PS29 project (CASMEZ, "Stratigraphic logs of the PS29 (Progetto Speciale 29) boreholes, catalogue", unpublished data, 1979) and the design and construction of the Western Campania Aqueduct. As part of the plan for the water-wells and other hydraulic infrastructures, numerous boreholes were drilled in the Cassino urban area and the Gari springs area, previously analyzed and redrawn in Saroli et al. 2014 - for example, borehole 1 (Fig. 3) intercepts the Messinian Quaternary clastic sequence, followed by the Mesozoic-Cenozoic limestone (top elevation of $-51 \mathrm{~m}$ a.s.1.). The elevation of the limestone sequence can strongly vary due to extensive normal faulting throughout the basin - for example, borehole 2 (Fig. 3) places the limestone top at $-302 \mathrm{~m}$ a.s.l. Surely, to investigate the existence of the groundwater flow from Gari to Peccia springs, the boreholes drilled at the extremities of the Trocchio and Porchio Mts. (Fig. 2a) are very important. All stratigraphic data (boreholes 3, 4, 5, 6) indicate the presence of bituminous calcareous breccias (up to $129 \mathrm{~m}$ thick, borehole 6) or also the presence of green clays (borehole 5) at the base of the limestone sequence. The origin of these deposits is controversial. Borehole 7 (Fig. 3), drilled between Trocchio and Porchio Mts. (Fig. 2a), just proves the horst and graben setting, in accordance with the Saroli et al. (2014) reconstruction and the Boni et al. (1986) model. Borehole 8, drilled between the Camino and Lungo Mts. (Fig. 2a), records a superimposition of the terrigenous complex on the limestone complex.

Despite the absence of an official stratigraphy, domestic water-wells $(9,10$ and 11 in Fig. 2a) represent a direct access to sample the groundwater in the MesozoicCenozoic carbonate aquifer at depth. Campopino boreholes (12 in Fig. 2a) represent a series of water-wells, 


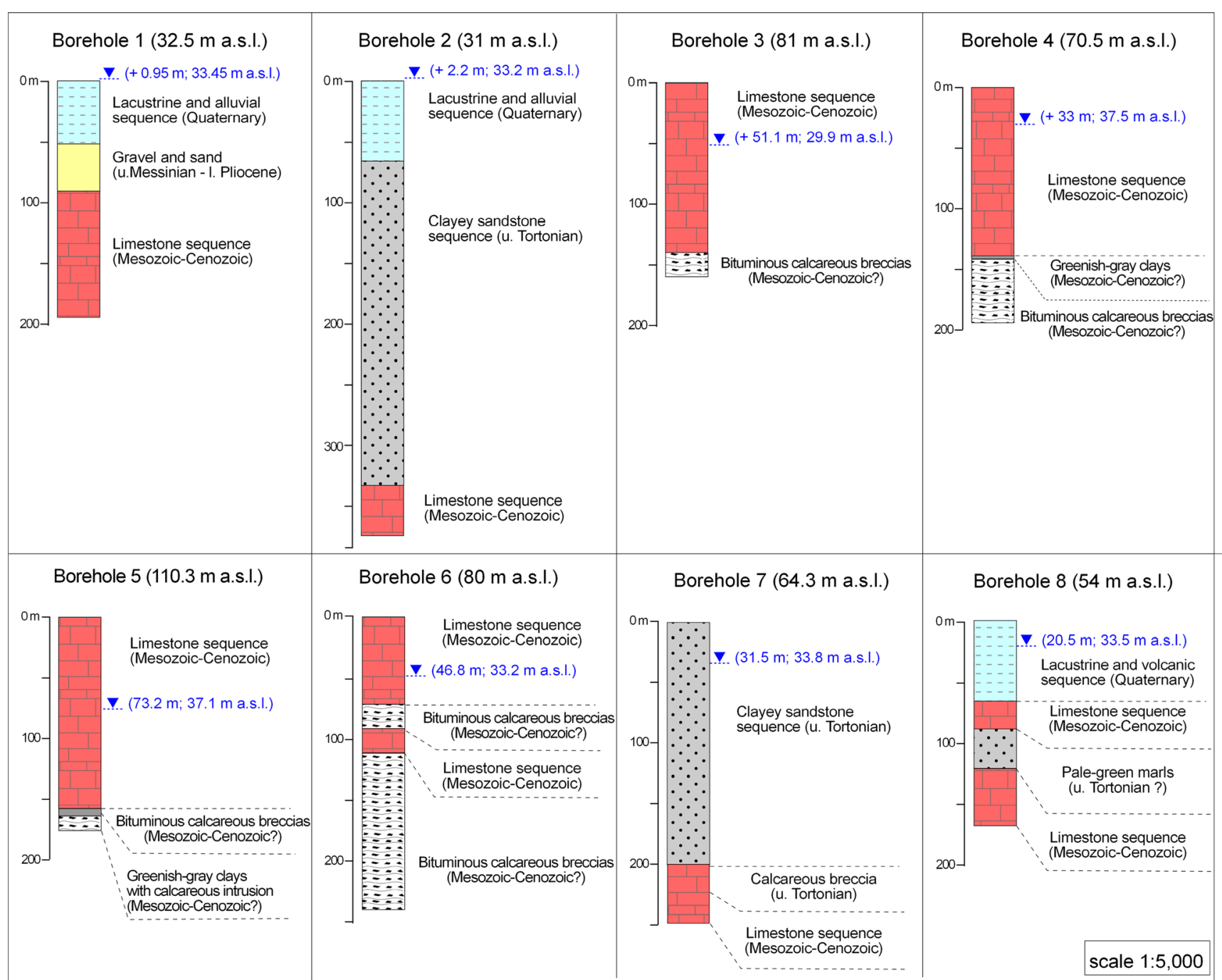

Fig. 3 Detailed stratigraphy of the most important boreholes in the central sector of Cassino plain. Borehole locations in Fig. 2a

drilled in correspondence with a tunneling bypass (Fig. 2a). The stratigraphy is monotonous and related to the dolomitic complex of the Venafro Mts.

\section{Results}

Taking into account existing data and the two proposed hydrogeological models, new investigations have been performed to clarify discrepancies between them. Due to the complex nature of the study area, a multidisciplinary approach, with literature data and new geological surveys along the small carbonate structures of the Cassino plain, was used to investigate the relationship between the Quaternary and less permeable terrigenous Tortonian complex. New investigations were conducted from a stratigraphic and structural point of view. The best geological reconstruction has been supported with groundwater level measurements and hydrogeochemical samplings. A detailed description of the new collected results is described in the following section.

\section{New geological data}

New stratigraphic data match with the geological sequences but still some discrepancies remain. Boreholes recorded widespread clayey breccias at the base of the Mesozoic limestone sequence (boreholes 3, 4, 5 and 6) or inside the Mesozoic sequence (borehole 8). Geological surveys focus on the Cassino plain and the structural setting of its small structures such as Trocchio and Porchio Mts. Surveys used a series of thin-sections to investigate the stratigraphic features of the Mesozoic to Miocene passage as well as better investigate the tectonic structure. Though the Mesozoic to Miocene passage is characterized by a stratigraphic hiatus (Corda and Brandano 2003), Eocene breccia with marls outcrops in correspondence with Porchio Mt. and Venafro Mts. (Fig. 2a). Zalaffi (1964) surveyed these deposits with uncertain age, 
vaguely from Eocene to Oligocene. New field surveys allow describing two facies:

- Calcarenites constituted by Cretaceous carbonate clasts from a guarded platform. Nummulites sp. and Alveolindae sp. indicate an Eocene age ('el' in Fig. 4a).

- Marly grainstone and marls characterized by spicules with cherty nodules, radiolarites, phosphate levels from organic matter, peloids and glass char, containing fishbones, alternated with bituminous levels. ('ebb' in Fig. 4a). The facies is younger than the previous (el) and indicated variations in the sedimentation style.

Important tectonic elements disturb the stratigraphic sequence, making an estimation of the Eocene thickness not possible; however, the sequence is terminated by a Cretaceous limestone sequence (cl in Fig. 4a,b) with a contractional fault (N130.50 oriented). Slickenside measurements testify to a strong strike slip component. The downward Eocene sequence is arranged via several low-angle contractional faults (Fig. 4a). The presence of bituminous levels and marly deposits (Fig. 4c) strongly suggests a ductile behavior. Indeed, tectonic splays of marly grainstones ('ebb' in Fig. 4) have been observed, while the foot-wall and hanging-wall consist of Eocene calcarenites (Fig. 4d). All the contractional faults of the Eocene sequence have a similar trend (averaging N130.40), roughly corresponding to the average dip-slip of the Porchio Mts. The structure is cut by contractional elements, interrupted by younger normal faults that put the carbonates and the Tortonian clayey sandstone in contact along the western side. At the northern and southern boundary of the Porchio Mt., normal faults with a strike-slip component mark the carbonate sequence down.

At Trocchio Mt., geological surveys show a depositional hiatus from Cretaceous to Miocene, a common stratigraphic feature of the Simbruini-Ernici-Cairo-Eastern Aurunci sector (Civitelli and Brandano 2005; Corda and Brandano 2003). The structure can be schematized as a SE merging monocline, elongated along a NE-SW trend. The northern tip of the structure shows a progressive rotation of the bedding from N130 to N90. The northern limit is characterized by a contractional release, via a high-angle fault (N170.80). The structure is strongly affected by normal faults with a NNE-SSW and NE-SE trend that mask the previous tectonic style. South of Trocchio and Porchio Mts., gray clays and Tortonian sandstone widely outcrop, only interrupted by the Cedro Hill carbonate structure. The latter consists of a block of Cretaceous platform limestone. Along the southern limit of the structure, limestone ('cl' in Fig. 4d) superimposes over the clayey sandstone complex ('ts' in Fig. 4d), via a contractional fault oriented N330.45, and associated N.60.45 conjugates. Along the Cervaro and San Vittore del Lazio (Fig. 2), surveys recorded an analogue geological setting. Surveys show a tectonic superimposition of Cretaceous platform limestone (texture varying from mudstone to wackestone) above the gray clays, via strike-slip tectonics. In the area, the most extended structure is La Chiaia Hill (Fig. 2a). Faults, oriented N.130.30 and 240.30, described as a contractional contact between Mesozoic dolostone and Miocene gray complex. To better clarify the geological setting surrounding the small carbonate structure, surveys have been extended across the Venafro Mts. piedmont band (Fig. 2a). In the studied area, the Atina-San Pietro fault has an N240.70 trend and delineates the south-western sector, where the Cassino plain is located. Evidence of this movement can be extended up to the upper Pleistocene (Bosi and Mercier 1993; Bosi 1994) since recent loose detrital and residual deposits are involved in the faulting process (Saroli and Moro 2012; Saroli et al. 2014); however, the latter lineament shows strike-slip evidences along the studied sector. In fact, fault planes with the same orientation of the normal fault trend, left strike-slip evidence (N240.70), and right strike-slip evidence (N60.80), have been observed along the foot-wall of the Atina-San Pietro normal fault. Eventually, the Montecassino sector (Fig. 2a) concludes the surveys. The bedding has a homogeneous dip direction (varying from N120 to N130) and a variable dip angle from horizontal to vertical conditions, moving from the top to the bottom of the slope. According to Saroli et al. (2014), the Montecassino hill is a limb of a recumbent anticline fold, with axis perpendicular to the regional Val Roveto-Val Comino thrust (Fig. 1) and NNE vergence. However, the structural setting is deeply influenced by successive normal faults with a NNE-SSW and NW-SE trend. Mesozoic limestone outcrops in the Cassino urban area (Terme Varroniane and Borgo Mastronardi, in Fig. 2a), represent horst of the last normal faulting event.

\section{Hydrogeological surveys}

Literature data and new geological data define a complex geological framework. Across the plain, carbonate limestones are arranged in a horst and graben system, in accordance with Boni and Bono (1974) and Boni et al. (1986); however, important contractional features have been detected at Porchio Mt., Cedro Hill and the other small carbonate structures of the Cassino plain, according to Celico (1978, 1983). In the Cassino urban area, new surveys from Capelli et al. (2012) define the Gari spring distribution, whereas Saroli et al. (2014) connect the water spring distribution with the carbonate horst and graben setting, in accordance with Boni et al. (1986), and Boni and Bono (1974) studied the Peccia springs in detail; therefore, collection of new hydrogeological data has been focused on the central portion of the Cassino plain. The first surveys were performed along the small carbonate structure in the central sector of the Cassino plain. Small seasonal springs have been observed 

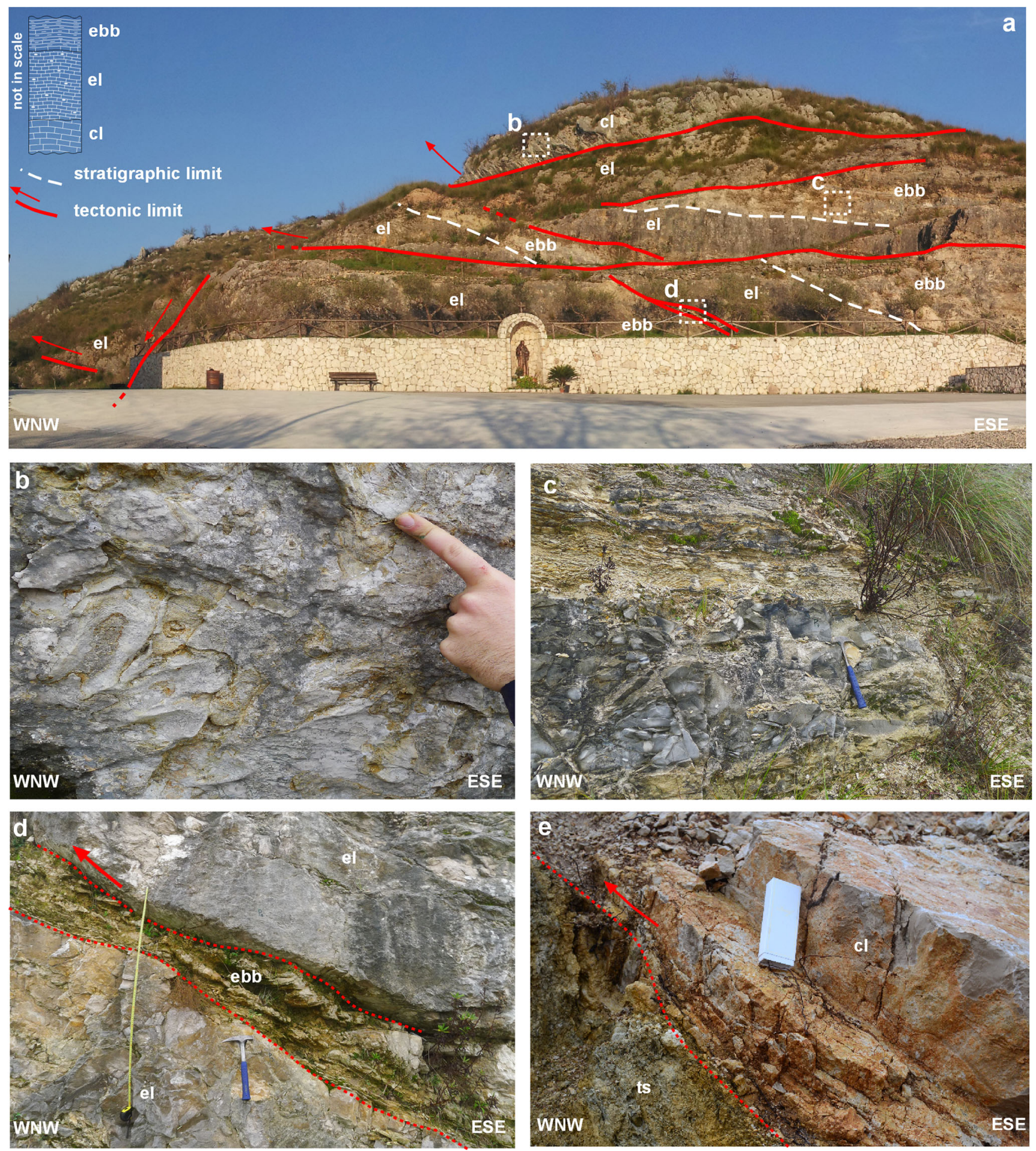

Fig. 4 a Surveyed evidence at Porchio Mt. Eocene sequence (ebb and el) arranged via several contractional faults and upwards delimited by Cretaceous boundstone with rudists; $\mathbf{b}$ detail of the Cretaceous boundstone with rudists (cl); $\mathbf{c}$ detail of the marls and bituminous breccias

facies (ebb); d detail of contractional fault with a doubling of Eocene limestone (el) sequence via a tectonic horse of Eocene bituminous marls (ebb), tectonic superimposition of Cretaceous limestone (cl) on Tortonian sandstone

along the small carbonate structures between Cervaro and San Vittore (Fig. 2). Despite their negligible discharge $(Q<1 \mathrm{~L} / \mathrm{s})$, small seasonal springs prove the hydrogeological isolation of the structures. Also, La Chiaia Hill (Fig. 2) feeds a small spring, the Oliveto Scuro Spring (elevation of $224 \mathrm{~m}$ a.s.l. and discharge of $27 \mathrm{~L} / \mathrm{s}$ ); thus, these hydrogeological structures are independent. No previous data existed for springs located along the borders of the Cedro Hill, Trocchio and 
Porchio Mts., so hydraulic head measurements were taken to define the groundwater flow and groundwater balance of these structures. Measurements were taken twice per year in correspondence of the dry and wet season, between 2014 and 2016. Hydraulic heads of surveyed boreholes are shown in the map of Fig. 2 (boreholes 3-11). In the carbonate aquifer of Porchio and Trocchio Mts., water levels vary between 29.9 and $37.5 \mathrm{~m}$ a.s.1, whereas values range from $41 \mathrm{~m}$ a.s.1. at Gari spring to $25 \mathrm{~m}$ a.s.l. at Peccia spring. Therefore, based on hydraulic head, water inside the structures is expected to flow towards the north in Trocchio Mt. and towards the south in Porchio Mt; however, a NE-SW flow, parallel to the supposed deep regional flow direction, has not been observed. Additionally, the hydraulic head of Cedro Hill, $65 \mathrm{~m}$ a.s.1., is higher than the previous hydraulic head dataset, making a hydrogeological correlation with surrounding carbonate structures and springs implausible.

\section{Hydrogeochemical analysis}

Additional hydrogeochemical and isotopic investigations have been performed to characterize the hydrogeological setting and groundwater flow of the studied area, as summarized in Fig. 5. Literature data of the Gari and Peccia springs and nearby karst groundwater (Boni and Bono 1974; Celico 1983) outline strong carbonate-calcium features. Boni and Bono (1974) suggest a contamination from the Roccamonfina volcano fluids towards the Lungo Mt.-Camino Mt. (Fig. 1), as shown in Suio gorge (Saroli et al. 2017). Literature data, new piezometric data, and aquifer and aquitard distribution were used to build a hydrogeochemical transect between Cairo Mt. and Venafro Mt. throughout the Trocchio-Porchio Mts. line. Samples were taken from the karst springs and water-well intercepting the limestone or dolostone aquifers. Classic hydrogeochemical analysis along the considered transects is represented in Fig. 5a. Hydrogeochemical analysis suggests pronounced calcium carbonate features, indicating circulation throughout the carbonate sequences; nevertheless, in correspondence with the Trocchio and Porchio Mts., analyses point out an enrichment of $\mathrm{Cl}^{-}, \mathrm{SO}_{4}{ }^{-2}, \mathrm{Na}^{+}$and $\mathrm{K}^{+}$, suggesting a shallower origin or a contamination. To further investigate, environmental isotopic analyses of ${ }^{2} \mathrm{H}$ and ${ }^{18} \mathrm{O}$ have been performed and plotted (Fig. 5b). Analysis took place at the Laboratory of Environmental Science M. Melloni (University of Parma, Italy) according to the methodology described in Longinelli and Selmo (2003). Groundwater with the maximum difference from V-SMOW comes from the Gari Springs group (Cassino urban springs, T. Varroniane Springs), representing the main discharge of the Simbruini-Ernici-Cairo Mts. hydrostructure. The S. Maria springs fed by the basal dolostone aquifer of the Venafro Mts. show similar results. A slight increase of isotopic values has been observed at Borgo Mastronardi Spring (Gari group) and S. Bartolomeo
Spring (Venafro Mts. group). Peccia springs and Campo Pino water-well show values that are progressively less depleted, due to the groundwater flow contribution coming from the Venafro Mts. having lower elevation (Fig. 2). Following the same trend, the Acquacandida Spring is located between Rapido R. and Peccia S. and characterized by a small recharge area. Conversely, collected samples at Trocchio and Porchio Mts. show values closer to the V-SMOW standard and indicate a lower elevation zone of recharge, vastly different from the karst hydrostructures that surround the study area. Thus, the Porchio Mts. water-well, entirely drilled in Eocenic calcarenites and Cretaceous limestone, confirms a disconnection of the local flow from the regional one.

\section{Discussion}

Newly collected data have supplemented the existing geological and hydrogeological conceptual model of the area allowing for the reconstruction of the geological evolution of the Cassino plain and groundwater flow in the entire area. The reinterpretation of the Cassino plain and its small carbonate structures sheds light on the continuity of the MesozoicCenozoic carbonate aquifer, from Gari to Peccia springs. Hydraulic head measurements and hydrogeochemical samples provide support for the new hypothesis created with the geological reconstruction. Understanding this most plausible conceptual model is critical to the successful management of the groundwater resources in the area.

\section{Geological evolution of the Cassino plain}

Cassino plain is a Quaternary intermontane basin characterized by a complex geological history. In the lower Jurassic, the platform is disrupted by a normal fault event; the Cairo Mt. sector continues the sedimentation of platform facies as well the Venafro Mts. sector changes to a slope-basin carbonate facies. The current facies passage corresponds to the Val Roveto-Atina-Caserta line, creating a facies boundary (Accordi and Carbone 1988). This line will represent a structural weakness important to the following tectonic events. The evolution of the orogenetic chain involves the Mesozoic to Cenozoic carbonate deposits and the Tortonian clayey sandstone in the foredeep, characterized by the intercalation of gravitative-tectonic flow of allochtonous gray clays. Between the upper Tortonian and the lower Pliocene (Centamore et al. 2007; Cosentino et al. 2010), the latter units are arranged in a fold and thrust geometry, and the Mesozoic to Cenozoic carbonate units are superimposed on the Tortonian sandstone and gray clays. Proof of the orogenetic phase is recognized at the southern limit of the Latina Valley via geophysics surveys (Cippitelli 2005; Centamore et al. 2007) and between Lungo and Camino Mts., where the doubling of the carbonate series is 


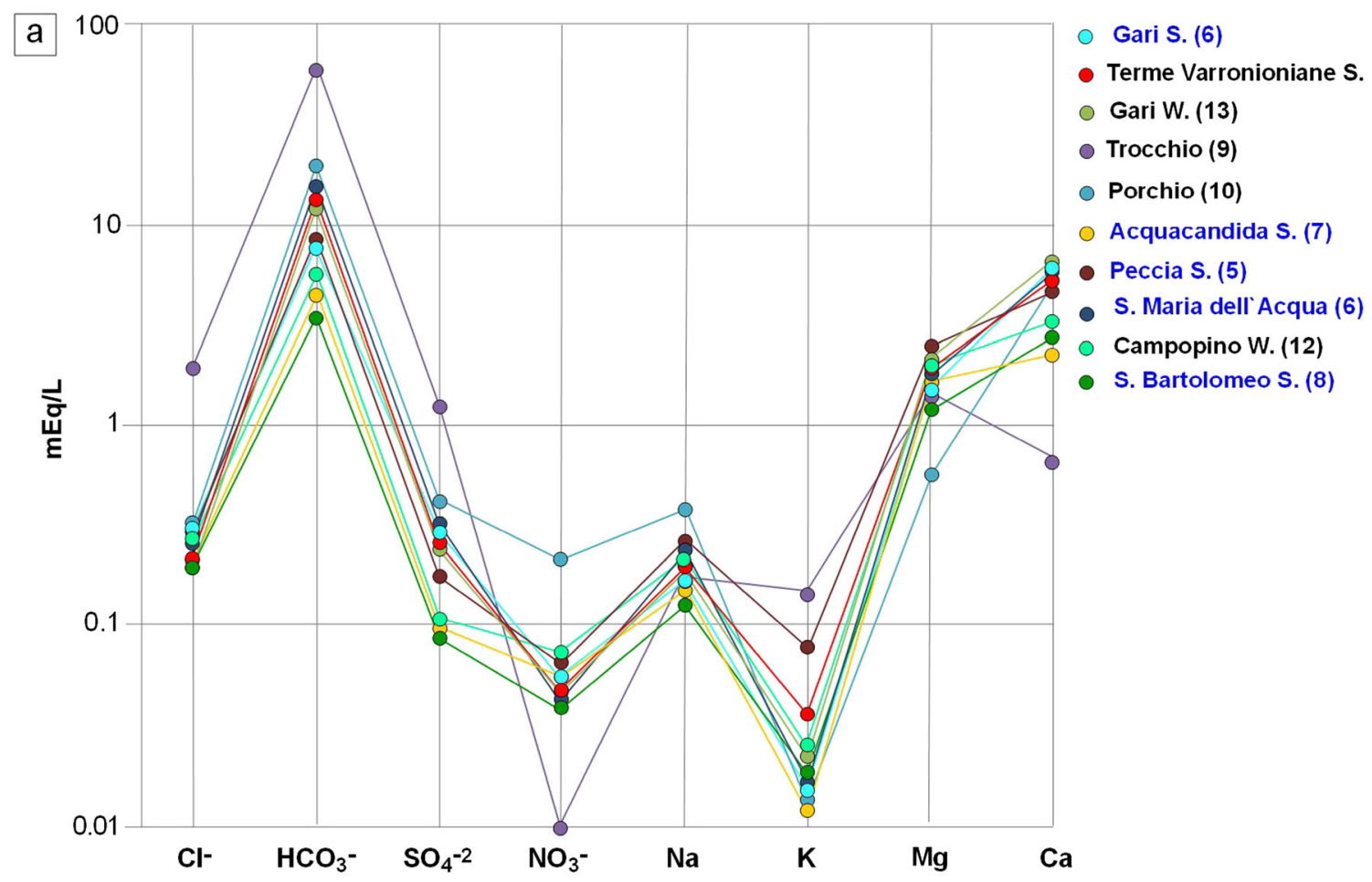

b

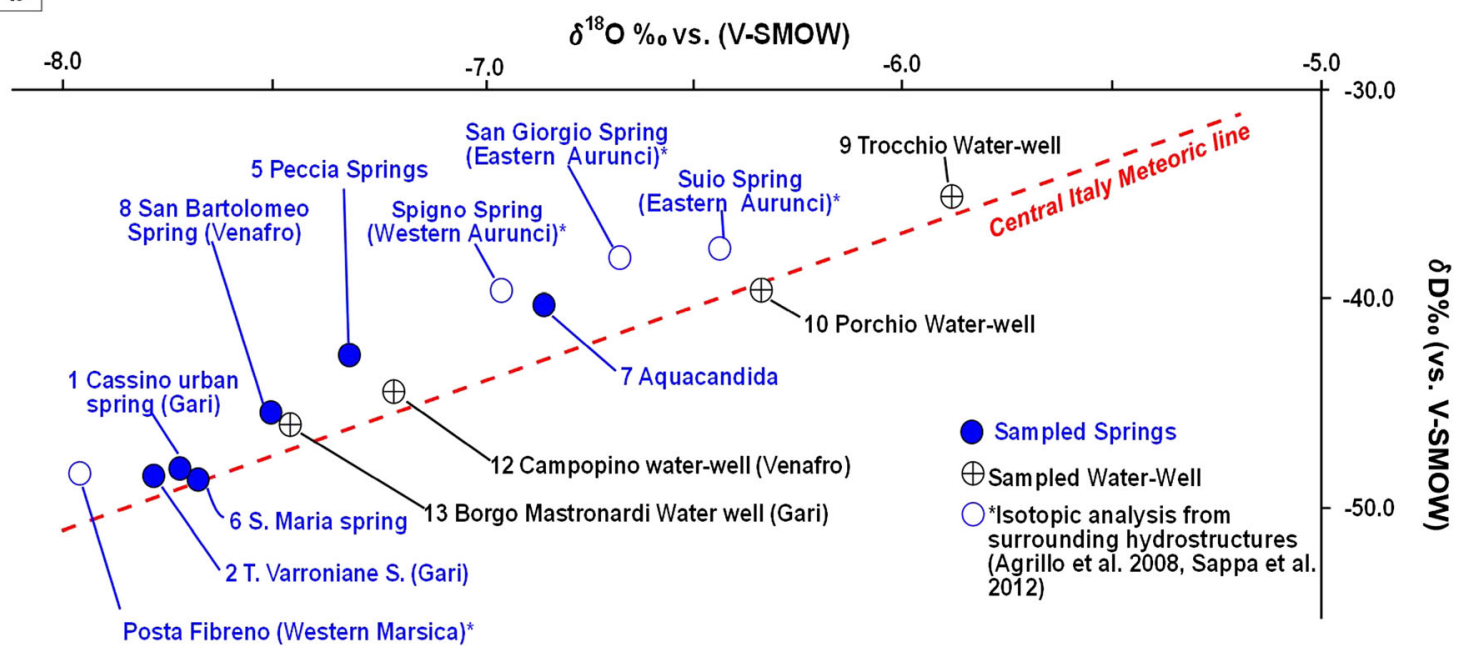

Fig. 5 a Schoeller diagram illustrating the hydrogeochemical composition of groundwater from Cairo to Venafro Mts., through the Trocchio and Porchio Mts. alignment. Analyzed samples indicate homogeneous carbonate-calcium features and proof of the strong interaction between groundwater and carbonate aquifers; $\mathbf{b}$ analysis of sampled environmental isotope furnished with data of surrounding hydrostructures. Data are well disposed along the Central Italy Meteoric

observed (Fig. 3, borehole 8). Thrusts have an Apennine direction and reflect the regional stresses that uplifted the orogenetic chain. The NW-SE limit of the Cairo unit is characterized by a NW-SE minor thrust which superimposes the carbonate units to the Tortonian sandstone. This element is interpreted as a minor lateral ramp that mechanically releases the Cairo Mt. and Venafro Mts. units during the chain structuring events or
Line (Longinelli and Selmo 2003). Water sampled at Trocchio and Porchio Mts. shows less depleted delta values, closer to the V-SMOW. It suggests a shallower origin, different from the regional flow feeding Gari and Peccia Springs from huge karst ridges. Isotopic data of Western Marsica Mts. comes from Agrillo et al. (2008); isotopic data of easternwestern Aurunci Mts. from Sappa et al. 2012

the successive contractional strike-slip tectonics. Analysis by Saroli et al. (2014) reveal a recumbent anticline fold (NE-SW axis and SW vergence) and indicate the propagation of this contractional element up to the Cassino plain. Nonetheless, the position of this element is still uncertain. Orogenetic contractional events can be grouped into a first tectonic phase (Fig. 6). The central sector of the Cassino plain, after the 
structuring chain processes, was strongly affected by the contractional strike-slip tectonics along the Roveto-Valley-AtinaCaserta line. Evidence of contractional strike slip tectonics is visible in the Atina area (Cavinato and Sirna 1988). Contractional tectonics expelled carbonate structures that overrode the Tortonian sandstone and grey clays, constituting carbonate klippen along the San Vittore-Cervaro-S. Elia area. Cedro Hill is also a carbonate klippen overridden on Tortonian sandstone, with contractional features. The Trocchio and Porchio Mts. sector, located between the San Vittore-Cervaro klippen and Cedro Hill, experienced contractional strike-slip tectonics, as well. Further evidence is visible along the south-

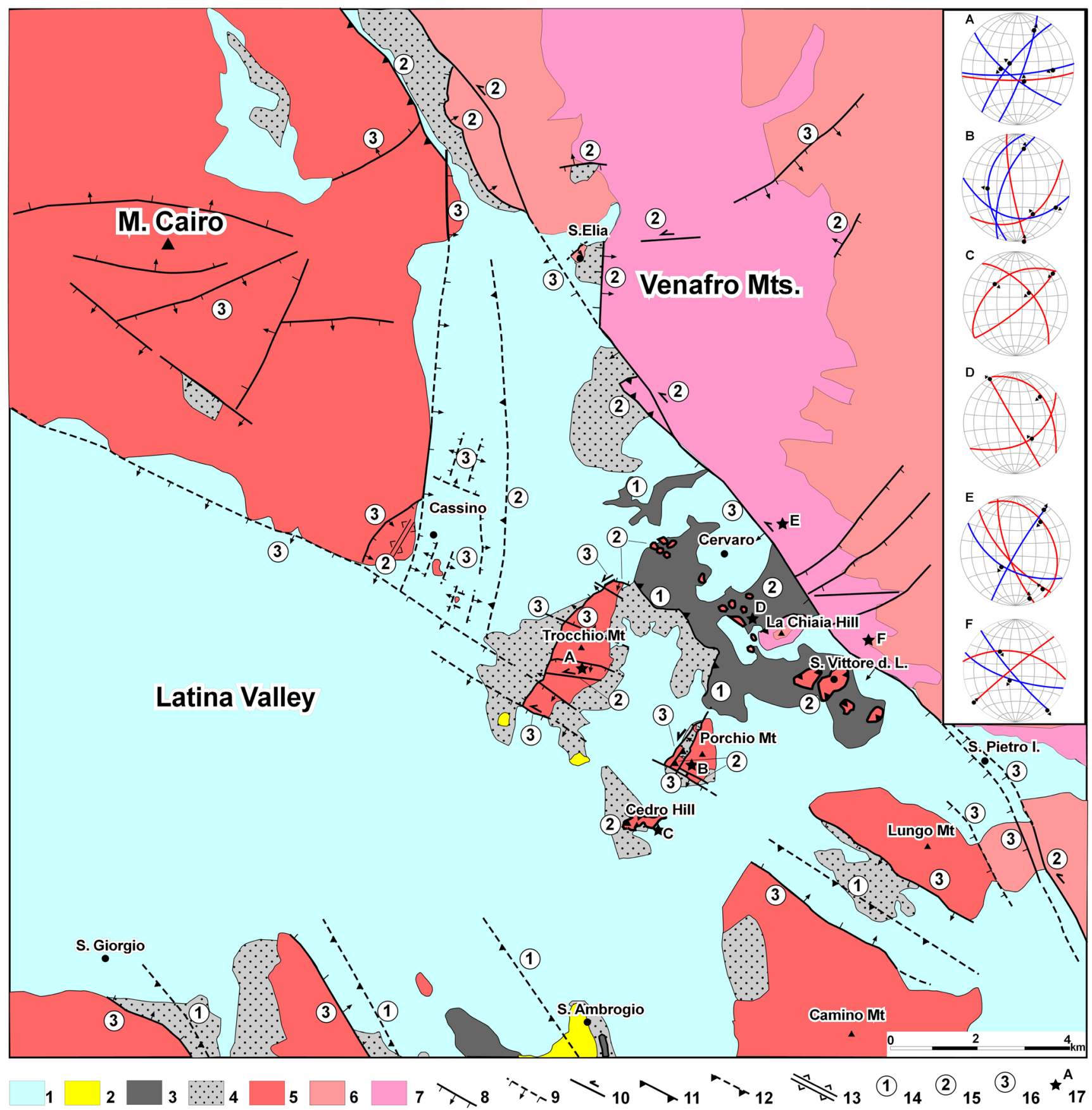

Fig. 6 Structural map of the Cassino plain. (1) Quaternary continental and lacustrine deposits; (2) Messinian to lower Pliocene sand and gravel deposits; (3) gray clays (Sicilidi Unis Auct.); (4) Tortonian Sandstone; (5) Cairo unit shallow-water carbonate sequence (Mesozoic-Cenozoic); (6) Venafro slope carbonate sequence (Mesozoic-Cenozoic); (7) basal dolostone (lower Mesozoic); (8) normal faults; (9) inferred normal faults;
(10) strike-slip faults; (11) thrust front; (12) inferred thrust front; (13) anticline fold axis; (14) orogenetic contractional tectonic phase; (15) transpressive tectonic phase; (16) normal faulting tectonic phase; (17) averaged structural plots. A-F letters indicate the structural plots of the southern hemisphere. Red lines refer to the contractional tectonic elements, blue lines normal tectonic elements 
western flank of Porchio Mt. with the superimposition of the cretaceous platform on the Eocene calcarenitic deposits (Fig. 4). Intercepted bituminous breccias (boreholes 3, 4, 5, 6 in Fig. 3) indicate the same contractional setting at depth for Trocchio and Porchio Mts. Investigated structures are delimited by bituminous breccias and clayey deposits at depth (facies el and ebb), with a strong influence on the regional groundwater flow. Transpressive elements are also responsible of the current position of the structures and can be grouped in a second tectonic phase (Fig. 6). Normal faulting events reused older tectonic lines. Along the Roveto Valley-Atina-Caserta line, a normal fault occurred, outlining the Cassino plain sector with evidence of normal tectonics up to the upper Pleistocene (Bosi and Mercier 1993; Bosi 1994; Saroli et al. 2014). The CairoTrocchio-Porchio-Lungo Mts. alignment is definitively arranged with a series of horst and graben, displaced along the NW-SE and NE-SW direction. Normal faults also truncate the southern flank of the Cairo Mt., Trocchio Mt. and Porchio Mt., defining the Mesozoic-Cenozoic carbonate sequence to over $-300 \mathrm{~m}$ a.s.1, (borehole 1 in Fig.3). Across the graben, Tortonian sandstone, Messinian-lower Pliocene piggy back deposits and Quaternary fluvial lacustrine are still preserved (borehole 2 in Fig. 3). These events can be grouped in the third phase (Fig. 6).

\section{Modified the hydrogeological conceptual model}

According to the literature review, the Mesozoic-Cenozoic carbonate complex constitutes the regional hydrostructure and the Tortonian sandstone and grey clays represent the regional aquitard. A new geological and hydrogeological section between Gari and Peccia springs has been created to review the hydrogeological conceptual model of the Cassino plain using literature data, new collected data, and the geological reconstruction (Fig. 7a). In accordance with Boni and Bono (1974), Celico (1983) and Boni et al. (1986), Gari springs represent the final destination of the groundwater flow coming from the Simbruini-Ernici-Cairo Mts. hydrostructure. Following the hydrogeological setting, major springs occur at the contact between the limestone and the alluvial complex at different elevations. Higher springs are located at the southern-eastern limit of the Cairo Mt. (Cassino urban springs; elevation 41$34 \mathrm{~m}$ a.s.l.). Groundwater flow by-passes the alluvial deposits due to the continuity of the lateral sequence, and springs are located along the limit of the horst structures located across the Cassino area, the Terme Varroniane spring (33-32 $\mathrm{m}$ a.s.l.) and Borgo Mastronardi spring (31-30 m a.s.l.). However, SE of the Borgo Mastronardi springs, the hydraulic head rises up to $37 \mathrm{~m}$ a.s.l., illuminating the cone of depression effect of the karst springs, as described by Boni and Bono (1974). Between Cervaro and San Vittore del Lazio, the small carbonate structures are clearly hydrogeologically isolated: they overlay Tortonian sandstone and grey clays and feed their own springs at their boundaries. Cedro Hill also overlays the Tortonian sandstone, and the measured hydraulic head is much higher than nearby spring elevations and surveyed water tables. The absence of springs can be easily justified with lateral seepage from the Mesozoic carbonate sequence to the permeable Quaternary layers. In fact, the elevation of the contact between the Mesozoic limestone and the Tortonian sandstone is higher than the surveyed hydraulic head; consequently, groundwater flows directly into the Quaternary layers. Trocchio and Porchio Mts. overlay Eocene bituminous breccias and clays, limiting the groundwater flow at their bottom. Geological surveys, borehole analyses, groundwater head distribution and environmental isotope data support the hydrogeological isolation of both Trocchio and Porchio Mts., in accordance with Celico (1978, 1983). Collected data do not highlight the presence of Tortonian sandstone at depth, in accordance with Boni et al. (1986). In addition, a doubling of the carbonate sequence cannot be excluded as well as a deep hydrogeological communication between Gari and Peccia springs; however, a numerical flow model from Lancia et al. (2018), calibrated to support a groundwater communication between Gari and Peccia springs, does not satisfy the quantitative balance suggested by Boni et al. (1986). Therefore, a deep flow communication in the carbonate bedrock is presumable, in accordance with the geological and hydrogeological models of Zalaffi (1964), Accordi et al. (1967), Boni et al. (1986), and Corda and Brandano (2003), but hydraulic head values are not sufficient to guarantee a significant groundwater flow from Gari towards Peccia springs. As final consequence, Gari and Peccia springs have been found to have independent feeding hydrogeological basins (Fig. 7b). SimbruiniErnici-Cairo Mts. hydrostructure feeds Gari spring, and Peccia spring represents the main delivery point of the Venafro Mts. hydrostructure (Fig. 8). Further investigations via trace elements could discriminate the relationship between Gari and Peccia springs, in a detailed manner.

\section{Implications for groundwater resource management}

The proposed hydrogeological conceptual model, summarized in Fig. 7b, shows that the Simbruini-Ernici-Cairo Mts. has its groundwater outflow in the Gari springs (elevation of 41-30 $\mathrm{m}$ a.s.1., discharge of $18,000 \mathrm{~L} / \mathrm{s}$ ). The hydrostructure is still underfed by a discharge of 4,000 L/s with an effective infiltration of $878 \mathrm{~mm} / \mathrm{a}$, lower than the theoretical value of $970 \mathrm{~mm} / \mathrm{a}$ (Fig. 8). The discharge of Gari springs is about 18,000 L/s (Fig. 8) and the missing discharge cannot be found in the Cassino plain, as recently suggested by Capelli et al. (2012). The absence of a groundwater flow from Gari to Peccia spring (Fig. 8) helps management of both groundwater withdrawals for the Western Campania Aqueduct and the project of new water-wells in the plain. Still, to complete the balance of the Simbruini-Ernici-Cairo Mts., lateral flow from 


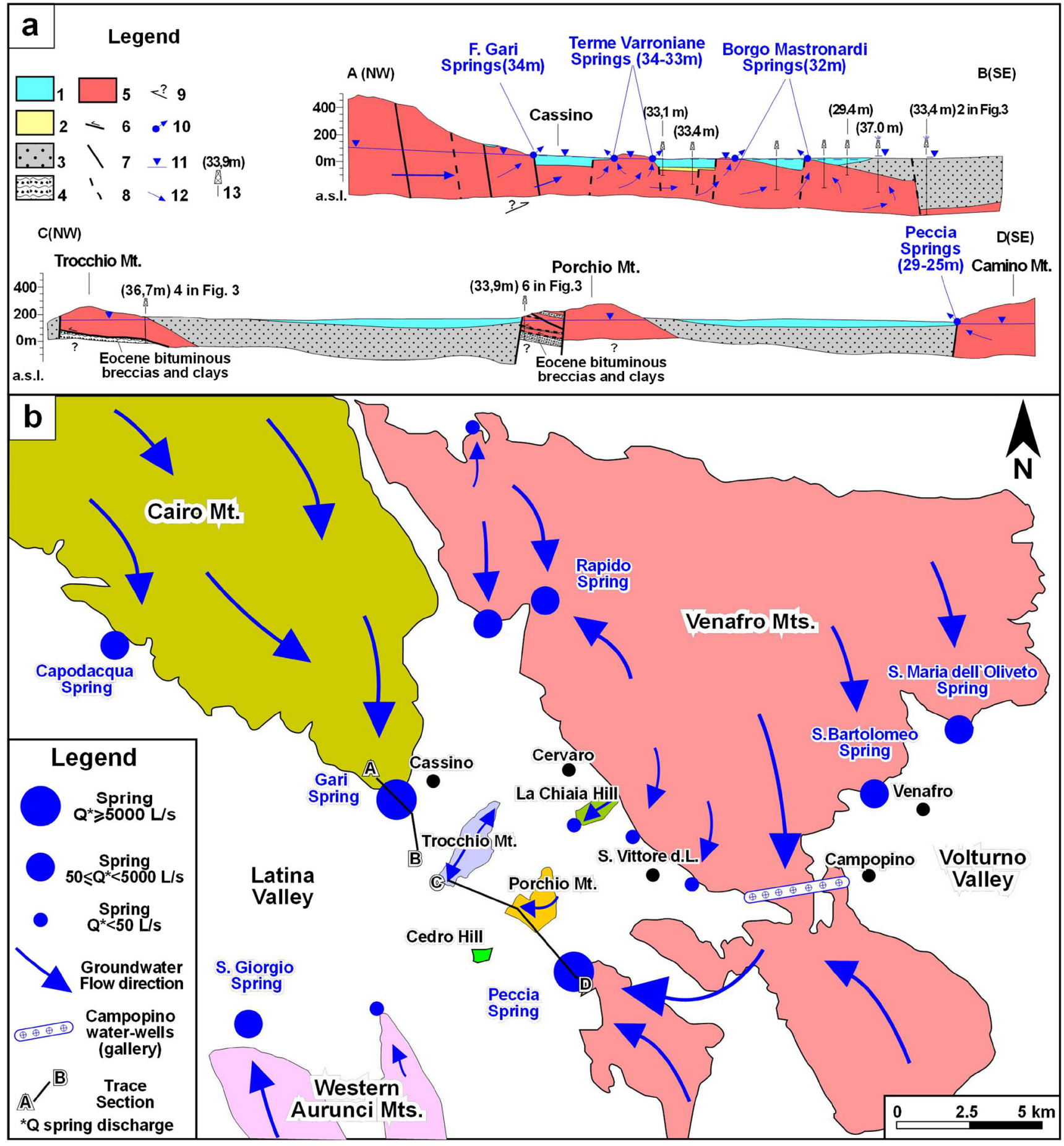

Fig. 7 a Conceptual hydrogeological sections from Gari to Peccia springs, section trace in Figs. $2 \mathrm{a}$ and $7 \mathrm{~b}$. In the Cassino area, groundwater flow emerges along the Terme Varroniane and Borgo Mastronardi horsts. Flow is interrupted outside the Cassino urban area, due to the thick pile of Tortonian flysch. Trocchio and Porchio Mts. are independent structures delimited at the bottom by Eocene bituminous breccias and clays, which are less permeable. Key to the legend: (1) Quaternary continental deposits; (2) Messinian to lower Miocene grave and sands; (3) Tortonian sandstone; (4) Eocene bituminous breccias and clays of the Venafro Mts. unit; (5) Cairo shallow-water carbonate unit; (6) contractional fault; (7) normal fault; (8) contractional normal fault; (9) inferred trust; (10) water springs; (11) reconstructed groundwater level; (12) groundwater flow direction; (13) borehole, numbers indicate elevation (m a.s.l.). b Hydrogeological conceptual model of the Cassino plain and Venafro Mts. Each color indicates a hydraulically separated karst basin. Small carbonate structures of the Cassino plain are also separated and hydraulically independent 


\section{Boniand Bono(1974), Boniet al (1986)}

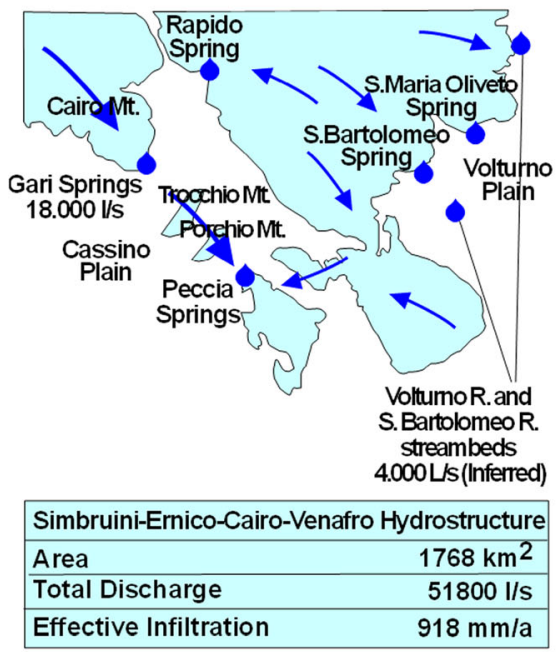

Celico $(1975,1976,1978,1983)$

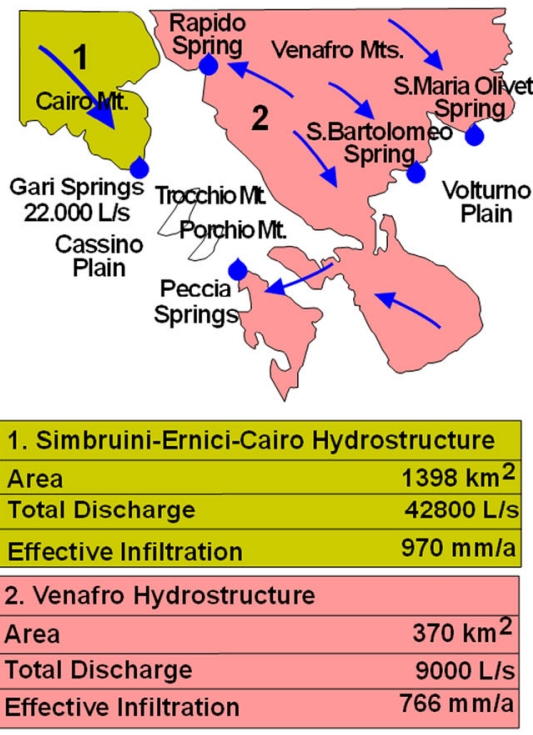

Proposed model

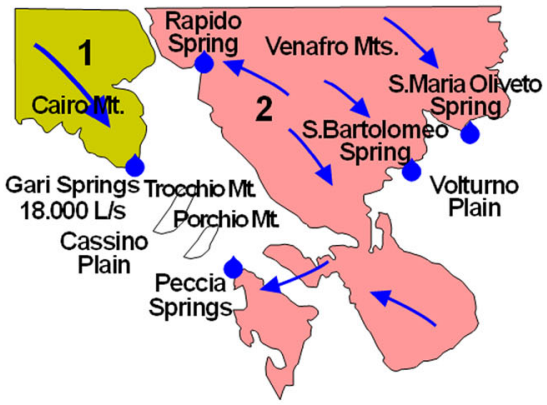

\begin{tabular}{|lr|}
\hline 1. Simbruini-Ernici-Cairo Hydrostructure \\
\hline Area & $1398 \mathrm{~km}{ }^{2}$ \\
\hline Total Discharge & $38700-42800 \mathrm{~L} / \mathrm{s}$ \\
\hline Effective Infiltration & $878-970 \mathrm{~mm} / \mathrm{a}$ \\
\hline
\end{tabular}

\begin{tabular}{|lr|}
\hline 2. Venafro Hydrostructure \\
\hline Area & $370 \mathrm{~km}^{2}$ \\
\hline Total Discharge & $9000 \mathrm{~L} / \mathrm{s}$ \\
\hline Effective Infiltration & $766 \mathrm{~m} \mathrm{~m} / \mathrm{a}$ \\
\hline
\end{tabular}

Fig. 8 Comparison between literature and the proposed model, with synthetic budgets. The main differences are related to the Gari spring discharge, the groundwater resources of the Volturno plain as well as the limit of the hydrostructures. Based on the proposed model, the Venafro Mts. hydrostructure results are independent, as already outlined by Celico $(1978,1983)$; however, the Simbruini-Ernici-Cairo Mts. hydrostructure is still underfed by a discharge of $4,000 \mathrm{~L} / \mathrm{s}$ with values of effective infiltration $(878 \mathrm{~mm} / \mathrm{a})$ lower than the expected ones, as tackled by Boni and Bono (1974) and Boni et al. (1986)

consequently, a groundwater flow from Gari to Peccia springs versus completely separated flowpaths between the springs), a literature review, new detailed geological and hydrogeological surveys and an updated hydrogeological balance were performed, as described in this report. Stratigraphic, tectonic, hydrogeological and hydrogeochemical data were gathered to validate the most convincing conceptual model of groundwater flow and to understand its potential impacts on the management of this massive water resource. Consequently, the main findings can be summarized in two separate issues: (1) the refinement of the hydrogeological conceptual model, necessary for improving groundwater management of the area, and (2) methodological answers, highlighting the usefulness of the followed multidisciplinary approach as examples for further research.

The findings of the work can be synthesized as follows:

planned as they could generate temporary changes of spring discharge. New geological and hydrogeological surveys, throughout the Venafro Mts. hydrostructure and the upper Volturno Valley combined with the groundwater recharge, will clarify these aspects in detail.

\section{Conclusions}

This multi-disciplinary investigation clarified the scientific debate between the Celico (1983) and Boni et al. (1986) hydrogeological conceptual models. Starting from their contrasting results on the hydrogeology of the Cassino plain (a horst and graben structure versus klippen tectonics and,
- Small carbonate structures of the Cassino plain were overlain on younger deposits, due to the contractional strike-slip tectonics. Cedro Hill and the small carbonate structures between Cervaro and San Vittore del Lazio are placed on Tortonian terrigenous complex or on gray clays and are hydrogeologically disconnected from the regional flow. Trocchio and Porchio Mts. are located on Eocene slope limestone and bituminous marls. Though these two structures are disconnected from the surrounding carbonate ridges in accordance with Celico (1983), a deep continuity of carbonate limestone under recent deposits of the plain is inferred in accordance with Boni et al. (1986). 
- The observed hydraulic loss along this NW-SE flowpath under the Cassino Plain would be sufficient to hinder significant flow between Gari and Peccia spring, in accordance with Celico $(1978,1983)$ and Lancia et al. (2018). Therefore, in terms of water management, Gari and Peccia springs must be considered independent to each other as well as their own recharge areas, respectively Simbruini-Ernici-Cairo Mts. and Venafro Mts. hydrostructures.

- This fine-tuned conceptual model is a useful tool for approaching challenges in groundwater management. Rejecting the communication between Gari and Peccia springs (Fig. 7b), the Simbruini-Ernici-Cairo Mts. are still overfed by a significant groundwater flow, about 4,000 L/ $\mathrm{s}$ (Fig. 8). This discrepancy necessitates a revision of the hydrogeological balance of this area to resolve the uncertainties. In the transition from a regional scale approach to a fine detailed conceptual model, additional investigations could provide more attention to minor springs and seepage flows, e.g. along streams, where the evaluation of interchanges can solve the inconsistencies found in the proposed model. Presumably, this still unknown discharge would represent a strategic resource for the economy of the entire region.

- Conversely, Venafro Mts. are an independent hydrostructure and Peccia springs represents its own final delivery (Fig. 8). In the light of the new findings, water management options have to be reconsidered and probably extraction rates reviewed. Throughout the Venafro Mts., water-table decline can reach critical point at the level of the eastern sector in correspondence with Santa Maria dell'Oliveto spring and San Bartolomeo spring. (Fig. 7b). In fact, if the quantity of water extraction becomes greater than the quantity of water recharged, these springs could reduce their flow rate until they disappear.

- From the methodological point of view, this research confirms that detailed analysis of stratigraphy and tectonics can represent a useful tool to support the groundwater studies throughout the perturbed karst sequence of the central Apennines. Aquifer limits and hydrological balances were defined more than 30 years ago (Celico 1983; Boni et al. 1986), when the thrust tectonics models of the central Apennines were at the beginning. A new reinterpretation of the hydrogeological data and related flow models could address new perspectives to better define the groundwater circulation and hydrostructure extents. Upscaling the regional groundwater flow models is a fundamental step to refine the hydrogeological balance at the hydrostructure scale. Similarly, a modern water management scheme based on groundwater resource assessment requires detailed and updated surveys, which take into account modern interpretations of structural geology and the influence on groundwater flow due to natural and/or human-induced changes. Actually, a modern management scenario, considering global-change effects, requires the optimization of groundwater exploitation respecting the renewable rate.

Acknowledgements The authors are grateful to Prof. M. Brandano, Prof. E. Patacca and Prof. P. Scandone for the discussion of the stratigraphic data of the Cassino plain. Prof. M. Barbieri and Dott. A. Nigro performed the hydrogeochemical analysis of the sampled water at the Geochemistry Laboratory of DST, Sapienza, and Prof. E. Selmo analyzed the stable isotopes at the Department of Chemistry, Life Sciences and Environmental Engineering. We appreciated their contributions. Managers of Acqua Campania S.p.A., Eng. G. Salvia and Eng. P. D'Andria, are acknowledged for sharing unpublished reports and providing the full access to the Western Campania Aqueducts. The authors are grateful to editors J.C. Comte and J.B. Aguillar, reviewer M. Barbieri and an anonymous reviewer for the useful suggestions.

This report is dedicated to Professors C.F. Boni, P. Bono, G. Capelli and P. Celico, pioneers of modern hydrogeology for central and southern carbonate Apennine. They, before us, dealt with the topic of groundwater communication for Gari and Peccia Springs. Consequently, we warmly thank them as mentors of our hydrogeological research; their powerful synthesis of groundwater resource allocation allowed us to discuss and to look into such detailed and current themes.

Open Access This article is distributed under the terms of the Creative Commons Attribution 4.0 International License (http:// creativecommons.org/licenses/by/4.0/), which permits unrestricted use, distribution, and reproduction in any medium, provided you give appropriate credit to the original author(s) and the source, provide a link to the Creative Commons license, and indicate if changes were made.

\section{References}

Accordi B (1966) La componente traslativa nella tettonica dell'Appennino Laziale-Abruzzese [The contractional strike-slip tectonics in the Lazio-Abruzzi Apennines]. Mem Soc Geol Ital 5:355-406

Accordi G, Carbone F (1988) Sequenze carbonatiche Meso-Cenozoiche [Carbonate sequences of the Mesozoic and Cenozoic]. In: Accordi G, Carbone F (eds) Carta delle Litofacies del Lazio-Abruzzo ed aree limitrofe. Q Ric Sci 111(5). CNR, Roma, pp 11-92

Accordi B, Angelucci A, Sina G (1967) Note illustrative della carta geologica d'Italia FF. Frosinone 159 e Cassino 160 [Illustrative notes of the geological map of Italy scale 1:100.000 FF. Frosinone 159 and Cassino 160]. Nuova Tecnica Grafica, Rome, 77 pp

Agrillo E, Bono P, Casella L, D'Andrea L, Fiori D (2008) Le sorgenti carsiche del Lago Fibreno: caratterizzazione idrologica, idrogeologica, idrochimica, isotopica [The karst spring of the Fibreno Lake: hydrology, hydrogeology, hydrochemistry and isotope characterization]. In: AA.VV. (2008) Atti della Prima Giornata di Studio "Tutela e conservazione dell'ecosistema acquatico Lago di Posta Fibreno area SIC/ZPS IT6050015". RNR and ARP, Rome, pp 55-81

Beneo E (1942) Le zone strutturali e le possibilità petrolifere della Valle Latina (Lazio) [The structural zones and the oil potential of the Latina Valley, Lazio]. Boll R Uff Geol Ital 67:5

Boni C, Bono P (1974) Segnalazione di un gruppo di grandi sorgenti nel bacino del Fiume Peccia, affluente del Garigliano [Evidence of meaningful water springs in the Peccia River basin, tributary of the Garigliano River]. Geol Rom 12:227-242

Boni C, Bono P, Capelli G (1986) Schema Idrogeologico dell'Italia Centrale [Hydrogeological scheme of central Italy]. Mem Soc Geol Ital 35:991-1012 
Bosi V (1994) Evoluzione neotettonica nel Lazio Meridionale-Campania Settentrionale in corrispondenza della terminazione meridionale della linea Ortona-Roccamonfina [Neoteconic evolution of the southern Lazio-northern Campania, in correspondence of the Ortona-Roccamonfina tectonic line]. PhD Thesis, VI cycle, Sapienza University, Rome

Bosi V, Mercier N (1993) Indizi di tettonica attiva nel Lazio Meridionale: l'esempio di San Pietro Infine (Caserta) [Evidence of active tectonic in southern Lazio: the San Pietro Infine case study]. Proceedings 11th Congress GNGTS, Bologna, Italy, November 2018 pp 287-296

Capelli G, Mastrorillo L, Mazza R, Petitta M, Baldoni T, Banzato F, Cascone D, Di Salvo C, La Vigna F, Taviani S, Teoli P (2012) Carta idrogeologica del Territorio della Regione Lazio, scala 1: 100.000 (4 fogli) [Hydrogeological map of Lazio, scale 1:100.000, 4 sheets]. Regione Lazio, S.EL.CA, Florence, Italy

Cavinato GP, Sirna M (1988) Elementi di Tettonica Transpressiva lungo la linea di Atina (Lazio Meridionale) [Contractional strike-slip tectonics along the Atina line, southern Lazio]. Mem Soc Geol Ital 41: $1179-1190$

Celico P (1978) Schema idrogeologico dell'Appennino carbonatico centro-meridionale [Hydrogeological scheme of the carbonate basins throughout the center-southern Apennines]. Mem Note Ist Geol Appl 14:50-52

Celico P (1979) Considerazioni sull'idrogeologia di alcune zone dell'Italia centro-meridionale alla luce dei risultati di recenti indagini geognostiche [Hydrogeological evidence in some areas of centralsouthern Italy via recent geognostic results] Mem Not Ist Geol Appl $15: 1-43$

Celico P (1983) Idrogeologia dell'Italia Centro-Meridionale [Hydrogeology of the central-southern Italy]. Q Cass Mezz 4(2)

Celico P, Stanganelli V (1976) Sulla struttura idrogeologica Dei Monti di Venafro (Italia Meridionale) [The hydrogeological structures of Venafro Mts., southern Italy]. Boll Soc Nat 85:153-178

Centamore E, Rossi D, Di Manna P (2007) Kinematic evolution of the Volsci range: a new overview. Boll Soc Geol Ital 12:159-172

Cippitelli G (2005) Oil potential of southern Latium, Latina Valley. FIST Epitome 1:123

Civitelli G, Brandano M (2005) Atlante delle litofacies e modello deposizionale dei Calcari a Briozoii e Litotamni nella piattaforma carbonatica Laziale-Abruzzese [The limestones in Briozoi and Litotamni in the Latium-Abruzzi carbonate platform (Central Apennines, Italy): atlas of the lithofacies and depositional model]. Boll Soc Geol Ital 124:611-643

Cipollari P, Cosentino D (1995) Miocene unconformities in the central Apennines: geodynamic significance and sedimentary basin evolution. Tectonophysics 252:375-389

Corda L, Brandano M (2003) Aphotic zone carbonate production on a Miocene ramp, central Apennines, Italy. Sed Geol 161:55-70

Cosentino D, Cipollari P, Marsili P, Scrocca D (2010) Geology of the central Apennines: a regional review. In: Meltrando M, Peccerillo A, Mattei M, Conticelli S, Doglioni C (eds) The geology of Italy: tectonics and life along plate margins. J Virt Expl 36, paper 12. https://doi.org/10.3809/jvirtex.2010.00223

De Vivo B, Rolandi G, Gans PB, Calvert A, Borhson WA, Spera FJ, Belkin HE (2001) New constraints on the pyroclastic eruptive history of the Campanian volcanic plain (Italy). Mineral Petrol 73:47-65

Devoto G (1965) Lacustrine Pleistocene in the lower Liri Valley. Geol Rom 4:291-336

Doglioni C, Innocenti F, Morellato C, Procaccianti D, Scrocca D (2004) On the Thyrrenian Sea opening. Mem Descr Carta Geol Ital 64:147-164

Fiorillo F, Petitta M, Preziosi E, Rusi S, Esposito L, Tallini M (2014) Long trend term and fluctuations of karst spring discharge in a
Mediterranean area (central-southern Italy). Environ Earth Sci 1: 153-172

Ford D, Williams P (2007) Karst hydrogeology and geomorphology. Wiley, Chichester, UK

Franchi S (1924) Il grande "slittamento" delle masse calcaree secondarie dei Monti Ausoni e Lepini sui terreni miocenici della Valle del Liri e della Valle Latina [The huge "skidding" of the Mesozoic carbonate sequence of Lepini-Ausoni Mts. on the Miocene deposit of the Liri and Latina valleys] C R Acc Naz Linc 33:60-66

Lancia M, Saroli M, Petitta M (2018) A double scale methodology to investigate flow in karst fractured media via numerical analysis: the Cassino plain case study (central Apennine, Italy). Geofluid, ID2937105, 12 pp. https://doi.org/10.1155/2018/2937105

Locardi E (1988) The origin of the Apenninic arc. Tectonophysics 146: $105-123$

Longinelli A, Selmo E (2003) Isotopic composition of precipitation in Italy: a first overall map. J Hyrol 270:75-88

Malinverno A, Ryan W (1986) Extension in the Tyrrhenian Sea and shortening in the Apennines as result of arc migration driven by sinking of the lithosphere. Tectonics 5:227-245. https://doi.org/10. 1029/TC005i002p00227

Novarese V (1926) La Valle Latina [The Latina Valley]. Mem Descr Carta Geol Ital 20:95-124

Parotto M, Praturlon A (1976) Geological summary of the central Apennines. In: Structural model of Italy. Q Ric Sci CNR 90:257-300

Pasquali V, Castorina F, Cipollari P, Cosentino D, Lo Mastro S (2007) I depositi tardo-orogenici della Valle Latina meridionale: stratigrafia e implicazioni cinematiche per l'evoluzione dell'Appennino Centrale [The late-orogenic deposits of the southern Latina Valley: stratigraphy and kinematic implications for the evolution of the central Apennines] Boll Soc Geol Ital 126:101-118

Patacca E, Sandone P (2007) Geology of the southern Apennines. Boll Soc Geol Ital 7(Spec Issue):75-119

Peccerillo A (2005) Plio-Quaternary volcanism in Italy. Springer, Berlin, $321 \mathrm{pp}$

Petitta M (2009) Idrogeologia della media valle del Fiume Velino e della Piana di S.Vittorino (Rieti, Italia Centrale) [Hydrogeology of the Velino River Valley and San Vittorino Plain, Rieti, central Italy]. Ital J Eng Geol Environ 1:157-181

Sappa G, Barbieri M, Ergul S, Ferranti F (2012) Hydrogeological conceptual model of groundwater from carbonate aquifers using environmental isotopes $(18 \mathrm{O}, 2 \mathrm{H})$ and chemical tracers: a case study in southern Latium region, central Italy. J Water Res Prot 4:695-716

Saroli M, Moro M (2012) Campoli Appennino, field trip guidebook. 16th joint geomorphological meeting, Rome, July 1-5, 2012

Saroli M, Lancia M, Albano M, Modoni G, Moro M, Scarascia Mugnozza G (2014) New geological data on the Cassino intermontane basin, central Apennines, Italy. Rend Fis Acc Lincei. https://doi. org/10.1007/s12210-014-0338-5

Saroli M, Lancia M, Albano M, Casale A, Giovinco G, Petitta M, Zarlenga F, Dell'Isola M (2017) A hydrogeological conceptual model of the Suio geothermal area (central Italy). Hydrogeol J 25:18111832

Scrocca D, Tozzi M (2000) Tettogenesi Mio-Pliocenica dell'area Molisana [Miocene to Pliocene orogenetic tectonics of the Molise region]. Boll Soc Geol Ital 118:255-286

Tallini M, Parisse B, Petitta M, Spizzico M (2013) Long-term spatiotemporal hydrochemical and $222 \mathrm{Rn}$ tracing to investigate groundwater flow and water-rock interaction in the Gran Sasso (central Italy) carbonate aquifer. Hydrogeol J 21:1447-1467

Zalaffi M (1964) Su alcune piccole strutture affioranti nella piana di Cassino [Notes on the small structures of the Cassino plain]. Mem Soc Geol Ital 4:1-14 